\title{
Macroeconomic indicators of raw material policy in Slovakia
}

\author{
Henrieta Pavolová ${ }^{1}$,Zuzana Šimkovád ${ }^{1, *}$, Andrea Seňová ${ }^{1}$, and Gabriel Wittenberger ${ }^{1}$ \\ ${ }^{1}$ Technical University of Košice, Faculty of Mining, Ecology, Process Control and Geotechnologies, \\ Institute of Earth Resources, Park Komenského 19, 04200 Košice, Slovakia
}

\begin{abstract}
This paper points to the development tendencies of selected macroeconomic indicators of raw material policy in Slovakia, which forms an integral part of the national economic policy of the state. It describes in detail selected macroeconomic indicators of exploitation of raw materials, which form the basic platform of functioning of all national economic sectors in Slovakia. It also points out the benefits for the Slovak economy in the form of revenues from mining activities to the state budget, municipal budget and environmental fund. At the end the article summarizes the partial findings from the development tendencies of macroeconomic indicators of raw material policy, which is currently an integral part of the industrial policy of the European Union.
\end{abstract}

\section{Introduction}

Raw materials are important strategic resources not only for individual sectors of the economy, for the EU as a whole, but also for individual states, because they bring considerable revenues to the state budget and at the same time support socio-economic development at a lower level - at regional level. But they are also a negative form of human perception, because mining is often associated with negative phenomena in the country. Not ignoring the political risk, associated not only with legislative parameters, but also with the dissatisfaction of citizens who are active participants in politics through elections [1]. This is the reason why should raw material (RM) policy also take their needs into account as well as sustainable economic growth, which is conditioned by providing of reliable RM supply and proper protection of living environment [34].

RM policy has become an integral part of the European Union's industrial policy. At the Member State level it requires connection with industrial policy, innovation policy, resource efficiency, environment and economic competition. This integrated perspective will enable industry to use the necessary RMs in a smart and sustainable way, what is contributing to the strategy "European Union 2020". For these reasons raw materials policies at EU Member State level should include the following partial activities:

- $\quad$ to promote resource efficiency, namely primary energy and RM resources, so as to divide economic growth from growth in resource consumption,

\footnotetext{
*Corresponding author: zuzana.simkova@tuke.sk
} 
- to strengthen research and development with regard to the possibility of replacing critical raw materials,

- $\quad$ to support existing or new RM extractions in Member States which are in-step with applicable environmental, social, health and safety legislation,

- $\quad$ to promote the supply of raw materials from domestic offer, these should be one of the pillars of all actions of RM policy,

- $\quad$ to maintain and increase employment in the European extractive sector by ensuring continuous education and training of the workforce, while the transition to more sustainable mining activities should be accompanied by social dialogue at all levels,

- $\quad$ to develop a coherent policy "urban mining" (extracting raw materials from municipal waste), which main goals is restoring and making available these resources of valuable raw materials,

- $\quad$ to promote the recycling of raw materials and the need to ensure the highest level of recycling where it is economically and technically feasible, including the exploitation of extractive wastes containing a significant amount and spectrum of different metals [2].

In addition to the above mentioned objectives of RM policy of EU in interaction with RM policy of Slovakia, we have analyzed guidelines, objectives, instruments, priorities, as well as national policies, plans, initiatives and measures with the impact and requirements for the efficient exploitation of raw materials as it is described in Table 1.

Table 1. Objectives of raw materials policy of Slovakia in the sense of the principles and principles of sustainable development.

\begin{tabular}{|c|}
\hline EU policies, directives, goals, tools, priorities with impact on raw material industry \\
\hline European raw material initiative \\
\hline European innovation partnership and Knowledge innovation community KIC RM \\
\hline Digital economy \\
\hline European technological platform for sustainable raw material sources \\
\hline EU policy in the area of raw materials: ERA-MIN \\
\hline EU policy in the area of raw materials: Circular economy \\
\hline EU tools: European Institute of Innovation and Technology (EIT) \\
EU tools: Horizon 2020 - SC5 \\
\hline Natura 2000 \\
\hline National policies, initiatives, and tools with impact on raw material policy \\
\hline Government Program Statement SR \\
\hline The strategy of permanent sustainable multispectral development and strengthening of \\
competitive ability of Slovakia \\
\hline Strategy for research and innovation for intelligent specialization SR \\
\hline Slovakian economic policy \\
\hline Energetic policy SR \\
\hline Circular economy SR \\
\hline Strategy Industry 4.0 SR \\
\hline Digital economy - unified digital market \\
\hline Environmental policy SR \\
\hline Program for the waste economy in SR 2016-2020 \\
\hline The conception of geological research in Slovakia \\
\hline
\end{tabular}

As we mentioned above, raw materials can be considered as a basic platform of all production processes of industries of the Slovak Republic (SR), which determine the continuous development of its economy. The majority part of raw materials includes nonore, construction and energy raw materials, while the production of larger part of non-ore and construction raw materials (limestone, dolomite, magnesite, gypsum, building stone, etc.) covers their domestic consumption in substantial rate. 


\section{Development of selected macroeconomic indicators of raw material policy in Slovakia}

The exploitation of raw materials directly and indirectly affects also to its socio economic area of sustainable development, which can be understood in accordance with $\S 6$ of Act No. 17/1992 Coll. about the environment as , development that meets the needs of the present generation without compromising the ability of future generations to meet their own needs and also do not cut nature diverse and also save natural functions of ecosystems".

In view of the above, we decided to follow the development tendencies of selected macroeconomic indicators of socio-economic area of raw materials exploitation, among which we included:

- gross value added,

- foreign direct investments,

- Gross Domestic Product,

- development of state revenues from the raw materials exploitation.

\subsection{Development of registered employment in the area of raw material policy of the SR}

Employment in mining organizations recorded more or less decreasing trend of development, which connected logically with development of RM mining and using of technical and technological equipment during RM mining in Slovakia. During whole analyzed period higher employment had been recorded for employees, working at surface mining, which is again logically connected with prevailing surface way of RM exploitation in Slovakia. The highest employment had been recorded in 2000, when employment achieved level 13968 employees (6 231 at deep mining and 7737 at surface mining) and on the other hand the lowest level was achieved in 2016, when employment decreased to 5476 employment (from which 1666 in underground and 3180 at surface mining. In following period total employment decreased to $45.5 \%$ of employment in 2000 with average number of employees 8273 employees.year ${ }^{-1}$.

In underground mining we recorded in analyzed period average employment - 3169 employees.year $^{-1}$ with its decrease in 2017 against 2000 by $62.3 \%$ (which means 3884 persons) from original employment. At the surface mining decrease of employment was rather smooth, when recording decrease by $48.2 \%$ (which means 3731 persons) from original employment in 2000, while averagely at surface mining 5105 employees.year $^{-1}$ had been employed (Fig. 1.). 


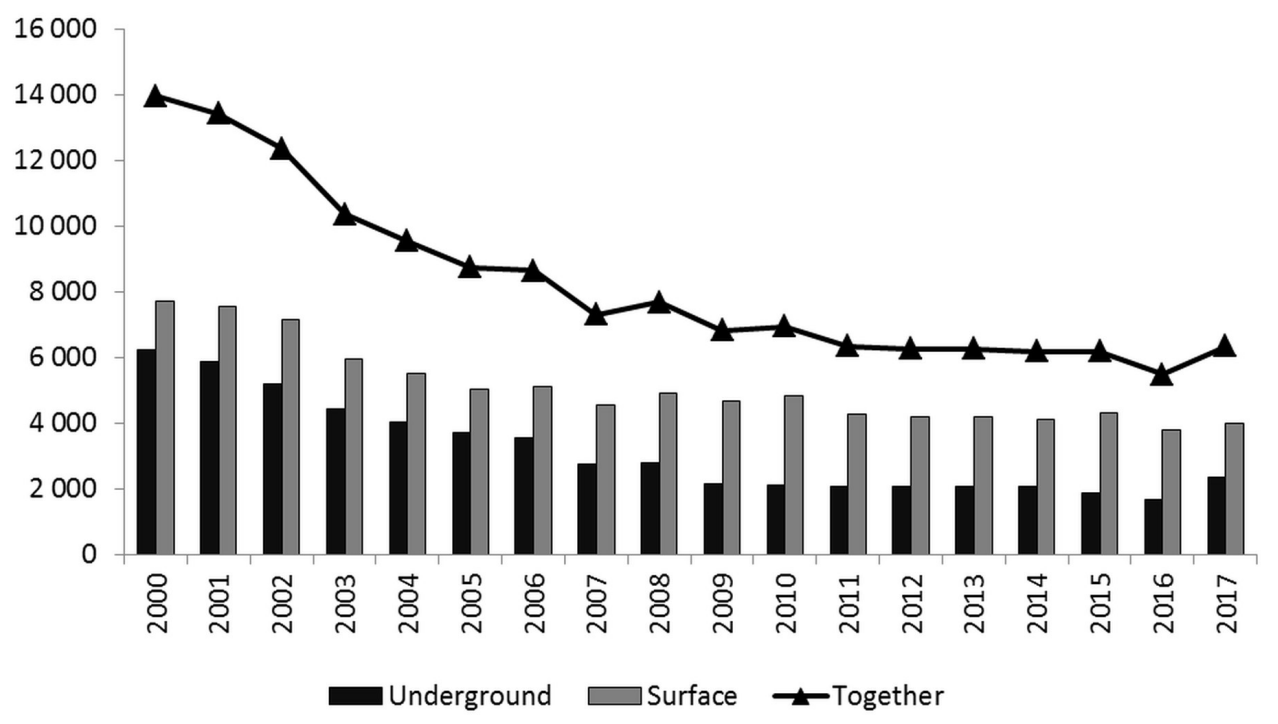

Fig. 1. Development of employment in mining organization of Slovakia [own processing according HBÚ].

\subsection{Development of gross value added in the field of raw material policy}

Exploitation of RM base contributes similarly to the creation of value added, which can be characterized as difference between production of commodities in basic prices and intermediate consumption of production factors in purchase prices. Production consists of products, produced in common accounting period and intermediate consumption consists of value of products and services, consumed in production process as inputs, excluding investment property, which consumption is reflecting in consumption of fixed capital. Also gross value added recorded in analyzed period fluctuating character of development with average value - 56616 mil. Eur.year ${ }^{-1}$, while the highest value was recorded in 2017, when this macroeconomic index achieved 73602 mil. Eur, on the other hand the lowest value was in 2000, when value added recorded 37698 mil. Eur (Table 2.). Similarly as employment development, also in the frame of gross value added creation in mining sector we recorded fluctuating tendency in analyzed period (Fig. 2.), while mining recorded average value added at level 295.81 mil. Eur.year ${ }^{-1}$, which means $0.53 \%$ average rate. Generally we can state that the highest value added in mining had been recorded in 2009 with level 372.83 mil. Eur, on the other hand the lowest value was recorded in 2000, when mining recorded value added at level 186.65 mil. Eur. Comparing 2000 and 2017 we found gross value added, produced by mining, decreased in 2017 against 2000 by 144.56 mil. Eur. The highest rate of mining on value added was recorded in 2003 with level $0.64 \%$. On the other hand the lowest rate of mining on value added decreased in 2017 against 2000 by $0.05 \%$ (Fig. 2.).

Table 2. Development of gross value added in Slovakia

\begin{tabular}{|c|c|c|}
\hline Year & $\begin{array}{c}\text { SR } \\
\text { [mil. Eur] }\end{array}$ & $\begin{array}{c}\text { Mining } \\
\text { [mil. Eur] }\end{array}$ \\
\hline 2000 & 37698,76 & 186,65 \\
\hline 2001 & 39486,60 & 187,48 \\
\hline
\end{tabular}




\begin{tabular}{|l|l|l|}
\hline 2002 & 41118,53 & 246,22 \\
\hline 2003 & 42973,05 & 275,94 \\
\hline 2004 & 44973,02 & 236,28 \\
\hline 2005 & 47492,91 & 249,22 \\
\hline 2006 & 52266,60 & 204,73 \\
\hline 2007 & 58021,92 & 328,49 \\
\hline 2008 & 61691,94 & 368,03 \\
\hline 2009 & 58314,00 & 372,83 \\
\hline 2010 & 61368,25 & 320,89 \\
\hline 2011 & 62898,59 & 344,24 \\
\hline 2012 & 64433,97 & 336,65 \\
\hline 2013 & 65167,74 & 337,71 \\
\hline 2014 & 66708,76 & 318,14 \\
\hline 2015 & 69295,49 & 352,96 \\
\hline 2016 & 71585,46 & 326,86 \\
\hline 2017 & 73602,75 & 331,21 \\
\hline
\end{tabular}

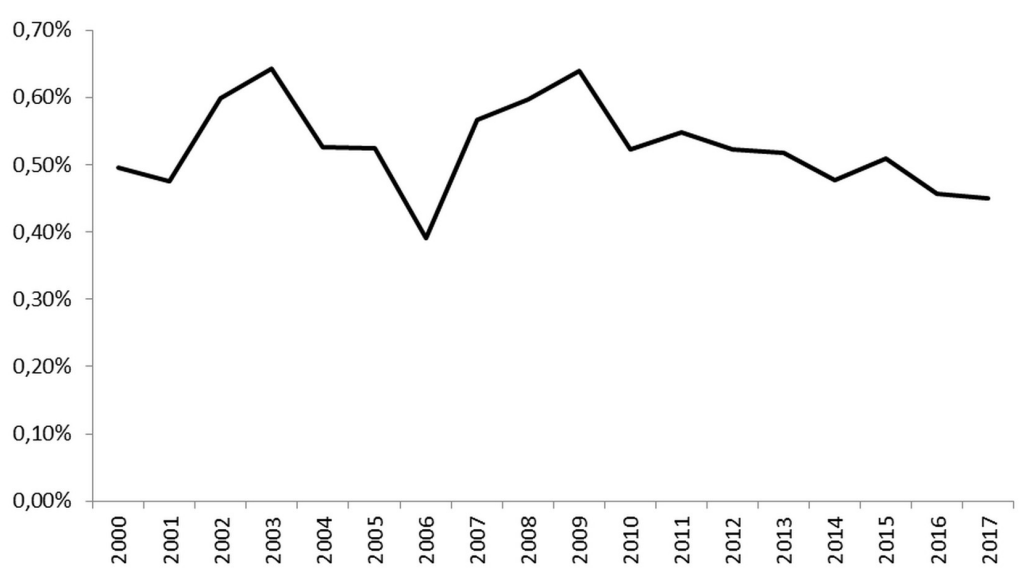

Fig. 2. Development of rate of mining on gross value added in Slovakia [own processing according SO SR]

\subsection{Development of foreign direct investments in the field of raw material policy of the SR}

Development of mining and connected single exploitation of RM base is determined also by domestic and foreign investments that support increasing of economic effectiveness. Mainly foreign direct investment (FDI) in Slovakia influences positively sustainable development, since they increase employment by creation of new working posts, GDP creation; they contribute to the implementation of innovative technologies or increasing of qualification of domestic human capital. FDI can be generally characterized as investment of money or other monetary values or rights with aim to base, obtain or 
extend permanent economic relations of domestic investor to business in abroad, resp. foreign investor investing to business in Slovakia. Mainly due to the mentioned FDI and rate of mining on FDI is considered as direct indicator of dynamic development of Slovakia in interaction with investment attractiveness of Slovakia for foreign investors. FDI development in Slovakia is characterizes more or less by increasing trend with slight decrease against 2013 by $2.62 \%$. According available data we can state that average FDI level in analyzed periods was approximately 27140447 tis. Eur.year $^{-1}$, while exploitation of RM base recorded average FDI level 232371 tis. Eur.year ${ }^{-1}$ (Table 3.), with average rate on total FDI in analyzed period at level $0.88 \%$.

Table 3. FDI development in Slovakia and mining

\begin{tabular}{|c|c|c|}
\hline Year & $\begin{array}{c}\text { SR } \\
\text { [tis. Eur] }\end{array}$ & $\begin{array}{c}\text { Mining } \\
\text { [tis. Eur] }\end{array}$ \\
\hline 2000 & 4097365,44 & 43508,43 \\
\hline 2001 & 5376306,25 & 65094,73 \\
\hline 2002 & 7270627,89 & 63859,35 \\
\hline 2003 & 12490727,63 & 71948,77 \\
\hline 2004 & 15141732,45 & 86089,53 \\
\hline 2005 & 19700181,02 & 102308,47 \\
\hline 2006 & 23338906,57 & 312402,28 \\
\hline 2007 & 29075292,32 & 300263,44 \\
\hline 2008 & 35846869,24 & 350298,28 \\
\hline 2009 & 36469023,00 & 396317,98 \\
\hline 2010 & 37665095,00 & 426960,00 \\
\hline 2011 & 40173448,00 & 476802,00 \\
\hline 2012 & 42304005,00 & 497996,00 \\
\hline 2013 & 42071874,94 & 211726,00 \\
\hline 2014 & 40969239,26 & 209928,00 \\
\hline 2015 & 42256452,00 & 102437,00 \\
\hline
\end{tabular}

\subsection{Development of Gross Domestic Product in the field of raw material policy of the SR}

Exploitation of RM base participates similarly as mentioned indexes of social and economic development also on the GDP development, which can be generally according Lisý et al., 2007 defined as "summary of final goods and services, produced and provided during certain time period by production factors in Slovakia, without regard to their state correspondence" [17]. GDP development had been ranked among basic indicators of economic effectiveness of Slovakia. Also this index, similarly as higher mentioned, recorded fluctuating trend. According available data we can state that in analyzed period 2000-2017 GDP recorded averagely 58313.5 mil. Eur.year $^{-1}$, while the highest value had been recorded in 2015 at level 78896.44 mil. Eur and on the other hand the lowest value was recorded in 2000 at level 31601.29 mil. Eur. Exploitation of RM base in Slovakia participated at the GDP creation in analyzed period averagely by 58313.5 mil. Eur.year $^{-1}$, while the highest level of RM base using on GDP in Slovakia had been recorded in 2008 
(371.3 mil. Eur) and the lowest value was in 2002 (154.3 mil. Eur) (Ошибка! Источник ссылки не найден..). At evaluation of rate of RM base on GDP creation we can state that this was directly determined by development of single GDP in interaction with development of mining sector that in analyzed period recorded average rate on single GDP creation in Slovakia $0.54 \%$ year $^{-1}$. Also rate of RM base using on GDP creation, similarly as higher mentioned analyzed indexes, recorded fluctuating trend, determined by GDP development in Slovakia, as well as by demand and offer development of single RM base. The highest rate of mining, which means using of RM base in Slovakia, was recorded in 2000, when the rate of mining on GDP creation in Slovakia achieved $0.79 \%$ and the lowest rate was in 2014, when the rate achieved only $0.42 \%$ (Fig. 3.).

Table 4. GDP development in Slovakia and mining

\begin{tabular}{|c|c|c|}
\hline Year & SR [mil. Eur] & Mining [mil. Eur] \\
\hline 2000 & 31601,286 & 161,2 \\
\hline 2001 & 34310,622 & 158,0 \\
\hline 2002 & 37279,842 & 154,3 \\
\hline 2003 & 41404,346 & 207,0 \\
\hline 2004 & 46101,527 & 160,7 \\
\hline 2005 & 50415,092 & 177,7 \\
\hline 2006 & 56272,653 & 204,2 \\
\hline 2007 & 63053,882 & 263,6 \\
\hline 2008 & 68491,623 & 371,3 \\
\hline 2009 & 64023,061 & 329,6 \\
\hline 2010 & 67577,288 & 358,1 \\
\hline 2011 & 70627,205 & 337,9 \\
\hline 2012 & 72703,513 & 330,3 \\
\hline 2013 & 74169,873 & 334,6 \\
\hline 2014 & 76087,789 & 319,8 \\
\hline 2015 & 78896,443 & 354,8 \\
\hline
\end{tabular}




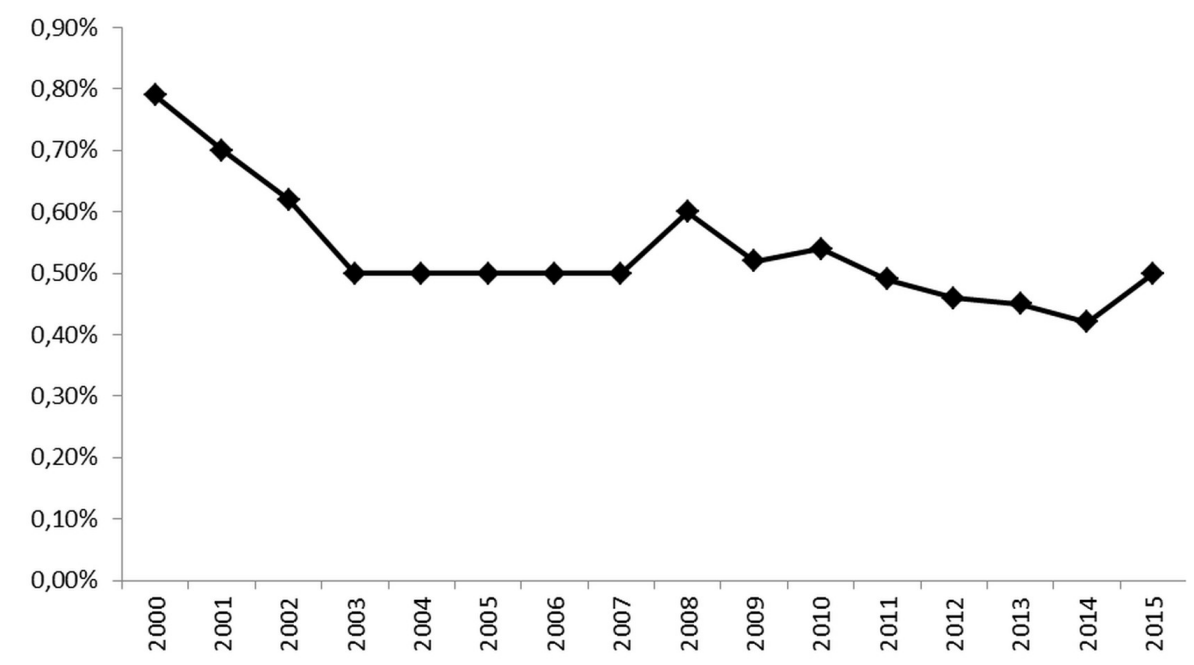

Fig. 3. Rate of mining on GDP in Slovakia [own processing according SGIDŠ]

\subsection{Development of revenues from mining activities into the state budget}

At higher mentioned development of employment in mining organization and development of average wage in SR we can state that income of state from payment from employees and employer by social security contributions presented averagely 2.78 mil. Eur.year-1 $^{-1}$, when the highest incomes were in 2007, presenting approximately 2.56 mil. Eur, which connected logically with development of average wage and number of employees, since in 2007 average annual wage in SR was 718.91 Eur and number of employees was 7312 and in 2017 average annual wage achieved 1095 Eur and number of employees in mining organizations was 6353 (Fig. 4.). Income of state budget, budget of administrations and environmental fund presented also payment for mining area, mined minerals and stocking gases. In analyzed period the highest incomes was created in 2007, achieving approximately $5.56 \mathrm{mil}$. Eur, from which only $2.3 \%$ presented payment for mining area (approximately 126.55 tis. Eur), 20.0\% payment for stocking gases (approximately 1.12 mil. Eur) and yet $77.8 \%$ (approximately 4.32 mil. Eur) presented payment for mined minerals (Fig. 5.). During analyzed period the highest rate of state budget income and administrations incomes presented payment for mined minerals, when its level is quantified according conditions amended by Government Decree No 50/2002 Coll. about payment for mining area, mined minerals and stocking of gases or liquids, as amended lately. Payment for mining area that presented lowest incomes of state and administrations is paid at the level $80 \%$ to administration, on which cadastral area the mining space is situated and $20 \%$ to state budget. 


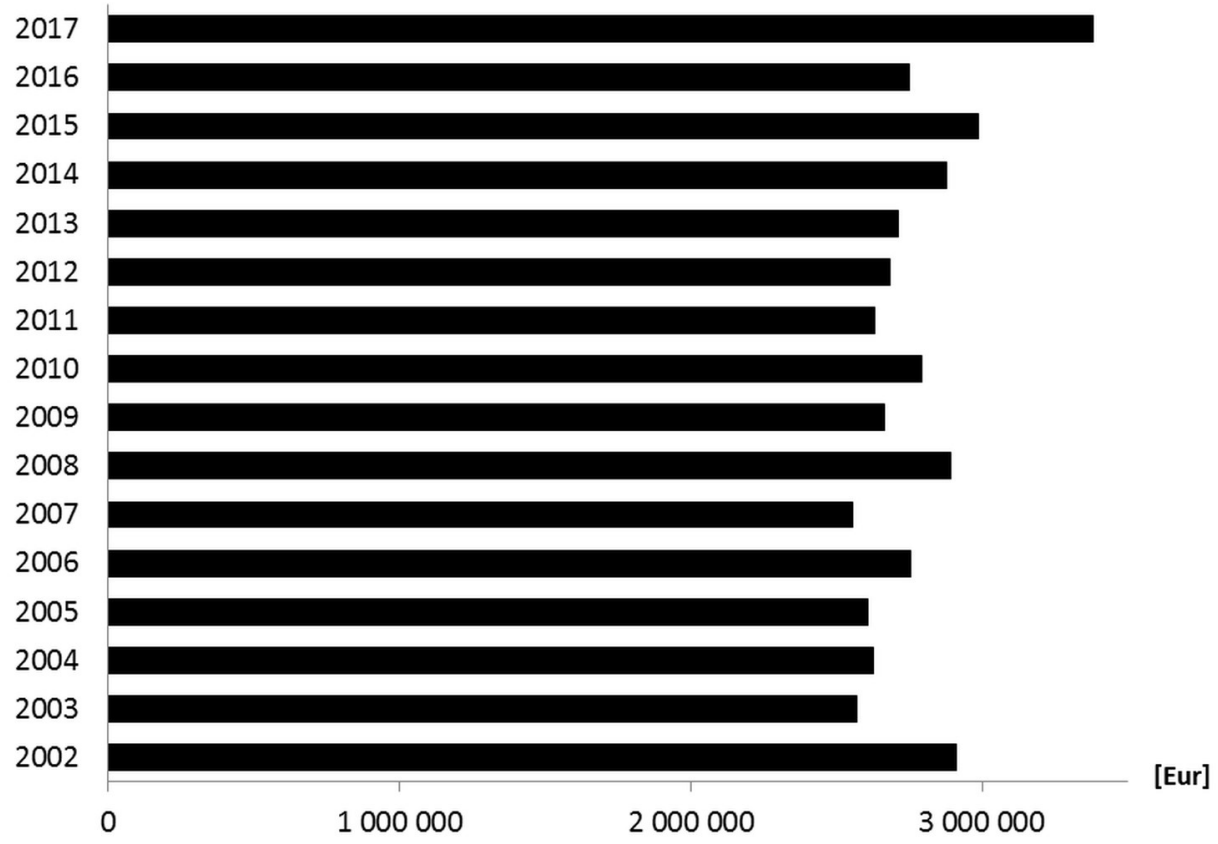

Fig. 4. State incomes from payment to social security of employees [own processing according HBÚ]

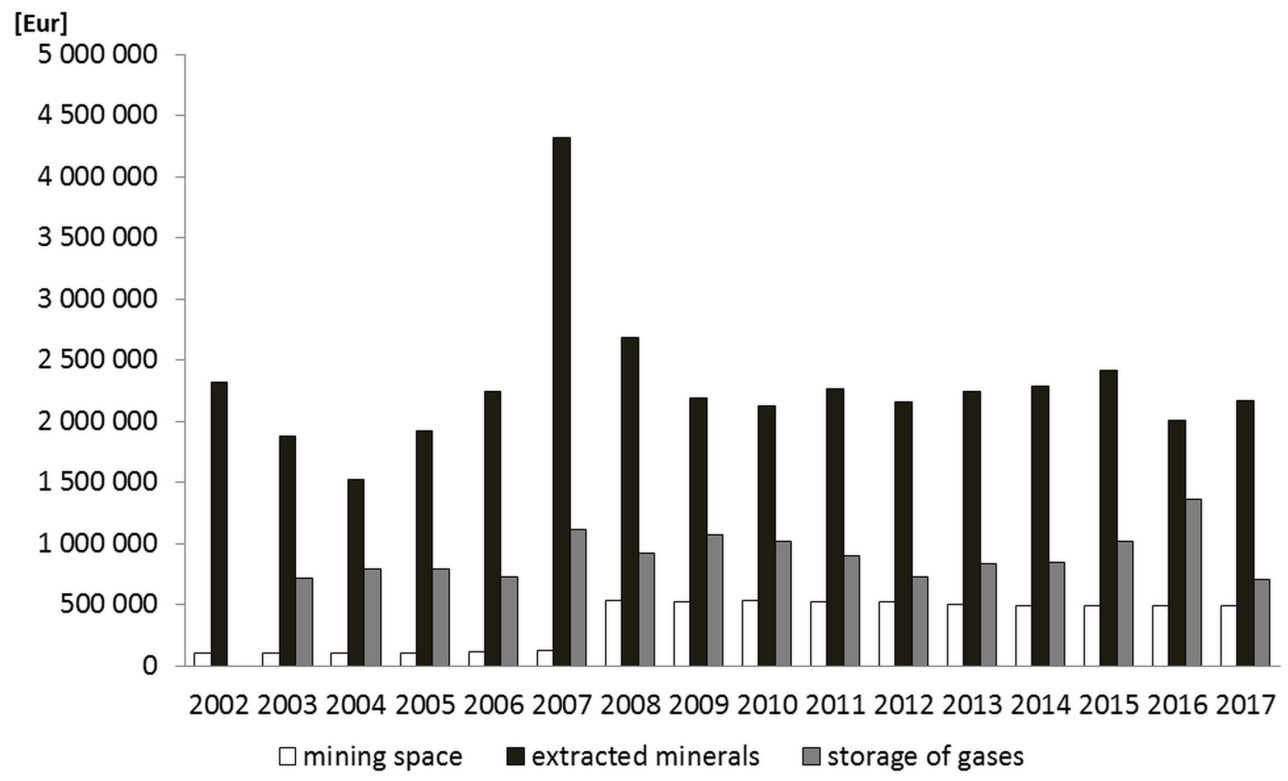

Fig. 5. Development of payment from RM exploitation in SR [own processing according HBÚ] 
Due to the higher mentioned we can state that RM using is characterized by positive impacts to social and economic area of sustainable development in Slovakia, which is different from the negative impacts to the environmental area of sustainability.

\section{Conclusion}

Based on a detailed quantitative analysis of the above monitored macroeconomic indicators, namely registered employment in the surface and underground mining of raw materials, gross value added, foreign direct investments, Gross Domestic Product, we could conclude that in the time horizon 2000-2015 they showed fluctuating trends, which was logically related to the development of industrial sectors of the economy, in which the raw materials form the basic platform of all production processes.

The same character of the development was recorded also in the case of the state revenues from employee and employer contributions by social security contributions, which was logically related to the character of registered employment development in the case of raw materials exploitation. The revenues of the state budget, municipal budget and the environmental fund, which consisted of payments for mining space, extracted minerals and gas storage, also showed fluctuating trends in the years 2002-2017.

During the period under review, the largest part of the state budget and municipal budgets was paid as a fee of the extracted mineral, which amount is quantified on the basis of the conditions regulated by the Decree of the Government of the Slovak Republic No. $50 / 2002$ Coll. about the reimbursement of the mining area, the reimbursement of the extracted minerals and the reimbursement for the storage of gases or liquids, as amended. Reimbursement for the mining area, which constituted the lowest revenues of the state and municipalities, is paid in the amount of $80 \%$ to the municipality in whose cadastral territory the mining area is situated and in the amount of $20 \%$ to the state budget.

\section{Acknowledgements}

Contribution is partial result of projects solving VEGA MŠVVaŠ SR 1/0515/18 „The decision-making model of process of evaluating raw material policy of regions".

\section{References}

1. M. Cehlár, L. Domaracká, I. Šimko, M. Puzder, Mineral resource extraction and its political risks (CRC Press/Balkema Leiden)

2. Európsky a sociálny výbor. Stanovisko Európskeho hospodárskeho a sociálneho výboru na tému na tému „Oznámenie Komisie Európskemu parlamentu, Rade, Európskemu hospodárskemu a sociálnemu výboru a Výboru regiónov: Riešenie problémov na komoditných trhoch a trhoch s nerastnými surovinami". URL: https://eur-lex.europa.eu/legalcontent/SK/TXT/PDF/?uri=CELEX:52011AE1177\&from=EN

3. HBÚ. 2005. Správa o činnosti Hlavného banského úradu a obvodných banských úradov Slovenskej republiky za rok 2004. URL: http:/www.hbu.sk/sk/Vyrocna-arocna-sprava/Rocne-spravy.alej

4. HBÚ. 2006. Správa o činnosti Hlavného banského úradu a obvodných banských úradov Slovenskej republiky za rok 2005. URL: http://www.hbu.sk/sk/Vyrocna-arocna-sprava/Rocne-spravy.alej 
5. HBÚ. 2007. Správa o činnosti Hlavného banského úradu a obvodných banských úradov Slovenskej republiky za rok 2006. URL: http://www.hbu.sk/sk/Vyrocna-arocna-sprava/Rocne-spravy.alej

6. HBÚ. 2008. Správa o činnosti Hlavného banského úradu a obvodných banských úradov Slovenskej republiky za rok 2007. URL: http:/www.hbu.sk/sk/Vyrocna-arocna-sprava/Rocne-spravy.alej

7. HBÚ. 2009. Správa o činnosti Hlavného banského úradu a obvodných banských úradov Slovenskej republiky za rok 2008. URL: http:/www.hbu.sk/sk/Vyrocna-arocna-sprava/Rocne-spravy.alej

8. HBÚ. 2010. Správa o činnosti Hlavného banského úradu a obvodných banských úradov Slovenskej republiky za rok 2009. URL: http://www.hbu.sk/files/documents/spravy/2009/spr\%C3\%A1va\%20o\%20\%C4\%8Din nosti\%20za\%20rok\%202009.pdf

9. HBÚ. 2011. Správa o činnosti Hlavného banského úradu a obvodných banských úradov Slovenskej republiky za rok 2010. URL: http://www.hbu.sk/files/documents/spravy/2009/spr\%C3\%A1va\%20o\%20\%C4\%8Din nosti\%20za\%20rok\%202009.pdf

10. HBÚ. 2012. Správa o činnosti Hlavného banského úradu a obvodných banských úradov Slovenskej republiky za rok 2011. URL: http://www.hbu.sk/files/documents/spravy/2011/spr\%C3\%A1va\%20o\%20\%C4\%8Din nosti\%20hb\%C3\%BA\%20a\%20ob\%C3\%BA\%20sr\%20za\%20rok\%202011.pdf

11. HBÚ. 2013. Správa o činnosti Hlavného banského úradu a obvodných banských úradov Slovenskej republiky za rok 2012. URL: $<$ http://www.hbu.sk/files/documents/spravy/2012/spr\%C3\%A1va\%20o\%20\%C4\%8Di nnosti\%20hb\%C3\%BA\%20a\%20ob\%C3\%BA\%20sr\%20za\%20rok\%202012.pdf

12. HBÚ. 2014. Správa o činnosti Hlavného banského úradu a obvodných banských úradov Slovenskej republiky za rok 2013. URL: http://www.hbu.sk/files/documents/spravy/2013/spr\%C3\%A1va\%20o\%20\%C4\%8Din nosti $\% 20 \mathrm{hb} \% \mathrm{C} 3 \% \mathrm{BA} \% 20 \mathrm{a} \% 20 \mathrm{ob} \% \mathrm{C3} \% \mathrm{BA} \% 20 \mathrm{sr} \% 20 \mathrm{za} \% 20 \mathrm{rok} \% 202013$.pdf

13. HBÚ. 2015. Správa o činnosti Hlavného banského úradu a obvodných banských úradov Slovenskej republiky za rok $2014 . \quad$ URL: http://www.hbu.sk/files/documents/spravy/2014/spr\%C3\%A1va\%20o\%20\%C4\%8Din nosti $\% 20 \mathrm{hb} \% \mathrm{C} 3 \% \mathrm{BA} \% 20 \mathrm{a} \% 20 \mathrm{ob} \% \mathrm{C3} \% \mathrm{BA} \% 20 \mathrm{sr} \% 20 \mathrm{za} \% 20 \mathrm{rok} \% 202014$.pdf

14. HBÚ. 2016. Správa o činnosti Hlavného banského úradu a obvodných banských úradov Slovenskej republiky za rok 2015. URL: http://www.hbu.sk/files/documents/spravy/2015/spr\%C3\%A1va\%20o\%20\%C4\%8Din nosti\%20hb\%C3\%BA\%20a\%20ob\%C3\%BA\%20sr\%20za\%20rok\%202015.pdf

15. HBÚ. 2017. Správa o činnosti Hlavného banského úradu a obvodných banských úradov Slovenskej republiky za rok 2016. URL: http://www.hbu.sk/files/documents/spravy/2016/sprava-o-cinnosti-hbu-a-obu-sr-zarok-2016.pdf

16. HBÚ. 2018. Správa o činnosti Hlavného banského úradu a obvodných banských úradov Slovenskej republiky za rok 2017. URL: $<$ http://www.hbu.sk/files/documents/spravy/2017/ro\%C4\%8Dn\%C3\%A1\%20spr\%C3 \%A1va\%202017.pdf

17. J. Lisý, Ekonómia v novej ekonomike (Bratislava: JURAEDITION, 2007)

18. Nariadenie vlády č. 50/2002 Z. z. o úhrade za dobývací priestor, úhrade za vydobyté nerasty a o úhrade za uskladňovanie plynov alebo kvapalín (Bratislava, Law, 2018) 
19. Slovak minerals yearbook 2002 (Bratislava, SGIDŠ, 2002)

20. Slovak minerals yearbook 2003 (Bratislava 2003, SGIDŠ)

21. Slovak minerals yearbook 2005 (Bratislava 2005 SGIDŠ)

22. Slovak minerals yearbook 2006 (Bratislava 2006, SGIDŠ)

23. Slovak minerals yearbook 2007 (Bratislava 2007, SGIDŠ)

24. Slovak minerals yearbook 2008 (Bratislava 2008, SGIDŠ)

25. Slovak minerals yearbook 2009 (Bratislava 2009, SGIDŠ)

26. Slovak minerals yearbook 2010 (Bratislava 2010, SGIDŠ)

27. Slovak minerals yearbook 2011 (Bratislava 2011, SGIDŠ)

28. Slovak minerals yearbook 2012 (Bratislava 2012, SGIDŠ)

29. Slovak minerals yearbook 2013 (Bratislava 2013, SGIDŠ)

30. Slovak minerals yearbook 2014 (Bratislava 2014, SGIDŠ)

31. Slovak minerals yearbook 2015 (Bratislava 2015, SGIDŠ)

32. Slovak minerals yearbook 2016 (Bratislava, SGIDŠ, 2016)

33. M. Taušová, E. Mihalíková, K. Čulková, B. Stehlíková, P. Tauš, D. Kudelas, L. Štrba, Sustainability, 11:10, 1-16 (2019)

34. Zákon č. 17/1992 Z.z. o životnom prostredí v zneni neskoršich predpisov (Bratislava, Law, 1992) 